\title{
New Late Cretaceous and Early Cenozoic decapod crustaceans from California, USA: implications for the origination of taxa in the eastern North Pacific
}

\author{
Torrey G. Nyborg ${ }^{1}$, Francisco J. Vega ${ }^{2}$ \& Harry F. Filkorn ${ }^{3}$ \\ ${ }^{1}$ Department of Natural Sciences, Loma Linda University, Loma Linda, CA 92350, USA; ${ }^{2}$ Instituto de \\ Geología, UNAM, Ciudad Universitaria, Coyoacán, México D. F. 04510, México; ${ }^{3}$ Department of Inverte- \\ brate Paleontology, Natural History Museum of Los Angeles County, 900 Exposition Boulevard, Los Ange- \\ les, CA 90007, USA
}

Keywords: Brachyura, Paleocene, Cretaceous, Costacopluma, Coeloma

\begin{abstract}
Recent revision of Cretaceous and Paleocene brachyurans in the collections of the Natural History Museum of Los Angeles County has revealed the presence of several new species. Based upon these fossils and their ages, it is evident that they played a pivotal role in the origination and subsequent dispersal of decapod crustaceans within the eastern North Pacific.
\end{abstract}

\section{Introduction}

Prior to this report, diverse occurrences of fossil decapod crustaceans had been reported from California (Rathbun, 1926, 1932; Squires, 1980, 2001; Bishop, 1988; Tucker et al., 1994; Schweitzer \& Feldmann, 2002). Furthermore, decapod crustaceans of Late Cretaceous and Early Cenozoic ages were believed to be quite rare in California (Schweitzer, 2001; Schweitzer \& Feldmann, 2002). However, the species described herein and the known Eocene decapod faunas from California (Rathbun, 1926; Squires, 2001; Schweitzer \& Feldmann, 2002) indicate that California is indeed a well-represented region for fossil decapod crustaceans.

\section{Mesozoic crustaceans}

The decapod fauna from the Maastrichtian Moreno Formation of Merced County, California, includes three species of brachyurans:

The first is Raninoides $\mathbf{n}$. sp., representing the earliest occurrence of the genus both in California and worldwide. The shape of the dorsal carapace, including the placement and lengths of the frontal spines, clearly justifies assignment to Raninoides. Well-presserved fossil material will allow a complete description of this new species and provide further insight into the evolution of the family Raninidae;

The second is Archaeopus n. sp., the second report of the genus from Upper Cretaceous rocks of California. The subquadrate carapace, long down turned front, relatively large orbits, and overall carapace shape allow confident assignment of this species to Archaeopus. Another species, $A$ antennatus, has been previously reported from an unnamed formation in the Upper Cretaceous of California (Rathbun, 1926). The new taxon differs in having a less subquadrate carapace and better defined regions than A. antennatus.

The third taxon is Icriocarcinus xestos, a species first reported from the late Campanian or early Maastrichtian Point Loma Formation of California (Bishop, 1988). This genus was originally placed in the Carcineretidae and subsequently reassigned to the Goneplacidae (Schweitzer et al., 2002). New material extends the geographic range of the genus northwards into central California. Currently, based upon very broad morphological characteristics, the genus Icriocarcinus is placed within the Goneplacidae (Schweitzer et al., 2002). With the many wellpreserved and complete specimens available for study now, it is hoped that the genus can be confidently placed at the family level. 


\section{Cenozoic crustaceans}

The Early Cenozoic occurrences of decapod crustaceans in California also are very significant. Decapod crustaceans from the middle to late Paleocene Coal Canyon Formation are the only specimens of this age known from the West Coast of North America. These specimens also are important because they indicate that certain Late Cretaceous decapod taxa persisted through the CretaceousTertiary $(\mathrm{K} / \mathrm{T})$ extinction event and survived at least into the Paleocene. Fîve species have been recognized:

The first species is Costacopluma n. sp. within Paleocene rocks of California confirms that the genus was widespread after the $\mathrm{K} / \mathrm{T}$ extinction event (Rẻmy, 1960; Collins \& Rasmussen, 1992; Collins et al., 1994; Feldmann \& Martins-Neto, 1995; Feldmann et al., 1995, 1997). A subrectangular carapace, narrow front, and angular cardiac region clearly allow placement of this species within the genus Costacopluma. Records of Costacopluma from the Mexcala Formation of the State of Guerrero, Mexico, suggest that this genus was present in America since Coniacian times (Vega \& Feldmann, 1992) and is as old (or possibly older) than the purported first record of the genus from Africa (Collins \& Morris, 1975). These findings indicate that the genus was well established in the eastern North Pacific region during its evolutionary span;

The second taxon is Coeloma $\mathrm{n}_{\mathrm{x}}$ sp., representing the earliest occurrence of the genus both in California and worldwide. The specimens referred here have a flat, trapezoidal carapace with a fourtoothed front and four teeth along the anterolateral margin. These morphological characteristics clearly permit the placement of this species within the genus Coeloma. Previously, the genus was believed to have dispersed to North America from Europe after the early Eocene (Schweitzer et al., 2002). However, with more than a dozen well-preserved specimens currently available for study, the genus now appears to have had its first appearance in California and subsequently dispersed to Europe by the early Eocene. Another species, Coeloma martinensis, was described from the late Eocene Martinez Formation of California by Rathbun (1926). The new species differs from $C$. martinensis in having a more distinct and projected front, more triangular anterolateral spines, and a less distinct medial frontal groove;

The third species is Archaeopus n. sp. is the first report of the genus in Paleocene rocks. The oldest occurrence is in Cretaceous strata of the west coast of North America (Rathbun, 1908; Schweitzer \& Feldmann, 2001; Schweitzer et al., 2002, submitted). The youngest occurrence is in the late Eocene of British Columbia, Canada (Schweitzer et al., submitted). The genus is endemic to the North Pacific with all but one of the fossil occurrences along the west coast of North America; Nagao (1941) described Archaeopus ezoensis from Cretaceous rocks of Japan.

The fourth taxon of note is Zanthopsis $\mathrm{n}$. sp. from the Paleocene of California clearly has the fourlobed front, vaulted carapace, and tubercles on the branchial region which justify placement of the new species within the genus Zanthopsis. With the reassignment of previous taxa referred to Zanthopsis (Beurlen, 1958; Bishop, 1988; Schweitzer et al., 2000), the present species is the earliest representative of the genus. Another species, Zanthopsis sternbergi, was reported from the Cretaceous of California (Rathbun, 1926), but it is only known from a questionable claw fragment and thus the occurrence of the species cannot be confirmed;

Finally, Cyclocorystes aldersoni also occurs in the Coal Canyon Formation, the species having been originally described by Squires (1980) on the basis of seventeen specimens collected from this formation. The only other species referred to this genus is the type species, Cyclocorystes pulchellus Bell, 1858, from the Eocene London Clay of England.

\section{Discussion}

The latest Cretaceous-earliest Cenozoic strata along the California coast of North America preserve a fairly robust record of the origination and evolution of fossil decapod crustaceans. Previously it had been postulated that southern latitude and Tethyan regions had a higher number of decapod taxa originations, with subsequent dispersals to the eastern North Pacific (Schweitzer, 2001; Schweitzer et al., 2002). However, with continued study of the deca- 
pod faunas from this region as exemplified by the above descriptions, it is becoming clear that many of the taxa described from rocks of the West Coast of North America actually. originated within the eastern North Pacific.

It has been reported (Schweitzer, 2001) that Cenozoic decapods from lower latitude regions, such as California, exhibit significant differences at the generic level from those occurring at higher latitude localities in Oregon, Washington, and British Columbia. Although there are only a few genera that can be found in every country and state from British Columbia to Mexico, there are actually many geographic overlaps along the margin of the continent. The genus Costacopluma, which is very common in the Upper Cretaceous of the eastern coast of Mexico (Vega \& Perrilliat, 1991; Vega et al., 1994, 1995), now has been recognised in the Paleocene rocks of California and undescribed specimens are known from British Columbia (J. Fam, pers. comm.). It is interesting to note that Costacopluma was as widespread during Paleocene times as it was during the Late Cretaceous. Archaeopus is found in Alaska, British Columbia, California, and Mexico. Ranina and Raninoides are found all along the west coast of North America. We agree with Schweitzer (2001) that more collecting and additional taxonomic studies of fossil decapods of the west coast of North America are needed before a comprehensive understanding of the originations and dispersal patterns of this group can be confidentially achieved for the eastern North Pacific.

\section{References}

Bell T. 1858. A monograph of the fossil malacostracous Crustacea, Part 1, Crustacea of the London Clay. Monogr. Palaeontogr. Soc. Lond. 1858: 1-44.

Beurlen K. 1958. Dois crustaceos do Cretaceo superior do Nordeste de Brasil (Decapoda: Brachyura). Bol. Mus. nac. Rio de Janeiro, Geol. 26: 1-23.

Bishop GA. 1988. Two crabs, Xandaros sternbergi (Rathbun 1926) n. gen, and Icriocarcinus xestos n. gen., n. sp., from the Late Cretaceous of San Diego County, California, USA, and Baja California Norte, Mexico. Trans. San Diego Soc. nat. Hist. 21: 245-257.

Collins JSH, Morris SF. 1975. A new crab, Costacopluma concava from the Upper Cretaceous of Nigeria. Palaeonto$\log y$ 18: 823-829, pl. 97 .
Collins JSH, Rasmussen HW. 1992. Upper Cretaceous-Lower Tertiary decapod crustaceans from West Greenland. Gronl. geol. Unders. Bull. 162: 1-46.

Collins JHS, Higgs R, Cortitula B. 1994. A new crab, Costacopluma bifida (Crustacea, Decapoda) from the Palaeocene of Venezuela. Bull. Mizunami Fossil Mus. 21: 29-34, pls 8, 9.

Feldmann RM, Martins-Neto RG. 1995. Costacopluma nordestiana $\mathrm{n}$. sp. (Decapoda: Retroplumidae) from the Maria Farinha Formation (Paleocene) of Brazil Jour. Paleo. 69: 610, 611 .

Feldmann RM, Fernanda Rodríguez M, Martínez GA, Aguirre-Urreta M. 1997. Costacopluma salamanca new species (Decapoda, Retroplumidae) from the Salamanca Formation (Danian) of Patagonia, Argentina. Jour. Paleo. 71: $125-130$.

Feldmann RF, Casadío S, Chìrino-Gálvez L, AguirreUrreta M. 1995. Fossil decapod crustaceans from the Jaguiel and Roca Formations (Maastrichtian-Danian) of the Neuquén Basin, Argentina. Mem. Paleo. Soc. 43: ii + 1-22.

Nagao T. 1941. On some fossil Crustacea from Japan. Jour. Fac. Sci., Hokkaido Imp. Univ. (4)6: 85-97.

Rathbun MJ. 1908. Fossil crabs from California. Proc. $U_{x} S$. natl Mus. 35: 3410349

Rathbun MJ. 1926. The fossil stalked-eyed Crustacea of the Pacific Slope of North America, U.S. natl Mus. Bull. 138: 1-155.

Rathbun MJ. 1932. A new species of Cancer from the Pliocene of the Los Angeles basin. Jour. Wash. Acad. Sci. 22: 19, 20.

Rémy JM. 1960. Sur les décapodes éocènes du Sénégal occidental. Étude géologique par A. Gorodískí. Étude paléontologique par J. M. Rémy. Bull. Soc. géol. France (7)1: 315-319.

Schweitzer CE. 2001. Paleobiogeography of Cretaceous and Tertiary decapod crustaceans of the North Pacific Ocean. Jour. Paleo. 75: 808-826.

Schweitzer CE, Feldmann RM. 2001. New Cretaceous and Tertiary decapod crustaceans from western North America. Bull. Mizunami Fossil Mus. 28: 173-210.

Schweitzer CE, Feldmann RM. 2002. New Eocene decapods (Thalassinidea and Brachyura) from southern California. Jour. crust. Biol. 22: 938-967.

Schweitzer CE, Feldmann RM, Tucker AB, Berglund RE. 2000. Eocene decapod crustaceans from Pulali Point, Washington. Ann. Carnegie Mus. 69: 23-67.

Sehweitzer CE, Feldmann RM, Gonzáles-Barba G, Vega FJ. 2002. New crabs from the Eocene and Oligocene of Baja California Sur, Mexico and an assessment of the evolutionary and paleobiogeographic implications of Mexican fossil decapods. Mem. Paleo. Soc. 59: 1-43.

Schweitzer CE, Feldmann RM, Fam J, Hessin WA, Hetrick S, Nyborg TG, Ross RLM. submitted. Cretaceous and Eocene crabs from the Nanaimo Group, British Columbia, Canada. Can. Jour, Earth Sci., Monogr. Series. 
Squires RL. 1980. A new species of brachyuran from the Paleocene of California. Jour. Paleo. 54: 472-476.

Squires RL. 2001. Additions to the Eocene megafossil fauna of the Llajas Formation, Simi Valley, southern California. Nat. Hist, Mus. Los Angeles Cty, Contr. Sci. 489: 1-55.

Tucker AB, Feldmann RM, Powell CL II. 1994. Speocarcinus berglundi $\mathrm{n}$. $\mathrm{sp}$. (Decapoda: Brachyura), a new crab from the Imperial Formation (late Miocene-late Pliocene) of southern California. Jour. Paleo. 68: 800-807.

Vega FJ, Perrilliat MC. 1991. Una especie nueva de cangrejo del género Costacopluma

(Crustacea: Decapoda: Retroplumidae) del Maastrichtíano del estado de Nuevo León. México Univx nac. Autón., Inst. Geol, Revista 8: 84-87.

Vega FJ, Feldmann RM. 1992. Occurrence of Costacopluma
(Decapodax Brachuyra: Retroplumidae) in the Maastrìchtian of southern Mexico and its paleobiogeographic implications. Ann. Carnegie Mus. 61: 133-152.

Vega FJ, Feldmann RM, Dávila-Alcocer VM. 1994. Cuticular structure in Costacopluma mexicana Vega and Perrilliat, from the Difunta Group (Maastrichtian) of northeastern Mexico, and its paleoenvironmental implications. Jour. Paleo. 68: 1074-1081.

Vega FJ, Feldmann RM, Sour-Tovar F. 1995. Fossil crabs (Crustacea: Decapoda) from the Late Cretaceous Cardenas Formation, east-central Mexico. Jour. Paleo. 69: 340350.

Received: 27 March 2003 